\title{
KESETARAAN LAKI-LAKI DAN PEREMPUAN DALAM HUKUM PERKAWINAN ISLAM
}

\author{
Rustam Dahar Karnadi Apollo Harahap \\ Fakultas Syariah dan Ekonomi Islam \\ IAIN Walisongo Semarang
}

\begin{abstract}
Abstrak
Perkawinan merupakan sebuah kontrak antara dua orang pasangan yang terdiri dari seorang laki-laki dan seorang perempuan dalam posisi yang setara. Seorang perempuan sebagai pihak yang sederajat dengan laki-laki dapat menetapkan syarat-syarat yang diinginkan sebagaimana juga laki-laki. Perkawinan secara mendasar berarti melibatkan diri dengan pembicaraan mengenai kasih sayang (mawaddah wa rahmah), dan hal inilah yang merupakan pokok pondasi suatu perkawinan. Dengan demikian hubungan antara suami dan isteri adalah hubungan horizontal bukan hubungan vertikal, sehingga tidak terdapat kondisi yang mendominasi dan didominasi. Semua pihak setara dan sederajat untuk saling bekerja sama dalam sebuah ikatan cinta dan kasih sayang.

Permasalahan perkawinan seringkali menjadi pemicu munculnya isu ketidaksetaraan dalam keluarga, padahal sejatinya Islam membawa norma-norma yang mendukung terciptanya suasana damai, sejahtera, adil dan setara dalam keluarga. Untuk menjawab berbagai berbagai pertanyaan seputar kedudukan laki-laki dan perempuan dalam hukum perkawinan Islam, tulisan ini akan mengungkapkan tentang berbagai kesetaraan dalam hukum perkawinan yang selayaknya dipahami agar tidak menimbulkan pandangan yang berat sebelah terhadap kelompok jender tertentu.
\end{abstract}

Kata Kunci: kesetaraan, hukum perkawinan Islam

\section{A. Pendahuluan}

Pada prinsipnya perkawinan dalam Islam membawa norma-norma yang mendukung terciptanya suasana damai, sejahtera, adil dan setara 
dalam keluarga. Akan tetapi karena pengaruh interpretasi ajaran yang kurang proporsional, maka tidak jarang terjadi beberapa rumusan ajaran Islam yang barkaitan dengan perkawinan tidak membela kepentingan (menyudutkan) peran perempuan. ${ }^{1}$

Dalam perspektif Islam, Perkawinan merupakan sebuah kontrak antara dua orang pasangan yang terdiri dari seorang laki-laki dan seorang perempuan dalam posisi yang setara. Seorang perempuan sebagai pihak yang sederajat dengan laki-laki dapat menetapkan syarat-syarat yang diinginkan sebagaimana juga laki-laki. ${ }^{2}$ Menurut Qasim Amin, sebagaimana dikutif oleh Rustam D.K.A.H., perkawinan secara mendasar berarti melibatkan diri dengan pembicaraan mengenai kasih sayang (mawaddah wa rahmah), dan hal inilah yang merupakan pokok pondasi suatu perkawinan sebagai dijelaskan dalam al-Qur'an: surat al-Rum, ayat 21. Dengan demikian hubungan antara suami dan isteri adalah hubungan horizontal bukan hubungan vertikal ${ }^{3}$, sehingga tidak terdapat kondisi yang mendominasi dan didominasi. Semua pihak setara dan sederajat untuk saling bekerja sama dalam sebuah ikatan cinta dan kasih sayang. ${ }^{4}$

${ }^{1}$ Perkawinan adalah merupakan satu sunnatullah yang umum berlaku pada semua makhluk ciptaan Allah SWT, baik manusia, hewan maupun tumbuh-tumbuhan. Dengan perkawinan tersebut makhluk hidup dapat berkembang biak untuk mengembangkan keturunannya sehingga dapat mempertahankan eksistesi kehidupannya di alam ini. Perkawinan, bagi manusia, sebagaimana makhluk-makhluk hidup yang lain, adalah suatu cara yang dipilih oleh Allah SWT. sebagai jalan untuk berkembang biak untuk kelestarian hidupnya, setelah masing-masing pasangan melakukan peranan yang positif dalam mewujudkan tujuan perkawinan. (Sayyid Sabiq, Fiqhu al-Sunnah, (Beirut: Dar AlFikr, tt.), II: hlm. 5).

2 Asghar Ali Engineer, Hak-hak Perempaun dalam Islam, terjemahan Farid Wajidi, (Bandung, LSPPA, 1994), hlm. 138. Lihat juga KHI, pasal 45 sebagai berikut: Kedua calon mempelai dapat mengadakan perjanjian perkawinan dalam bentuk:1. Taklik talak dan 2 . Perjanjian lain yang tidak bertentangan dengan hukum Islam.

${ }^{3}$ Rustam Dahar Karnadi Apollo Harahap, "Pola Emansipasi Wanita di Mesir (Pemikiran Qasim Amin)", dalam Bias Jender dalam Pemahaman Islam, ed. Sri Suhandjati Sukri, (Yogyakarta: Gama Media, 2002), hlm. 199.

${ }^{4}$ Dalam KHI, defenisi perkawinan menurut hukun Islam, pernikahan adalah akad yang sangat kuat atau mitssaqan ghalidzan untuk mentaati perintah Allah dan melaksanakannya merupakan ibadah. Perkawinan bertujuan untuk mewujudkan kehidupan rumah tangga yang sakinah, mawaddah, dan rahmah. (KHI, Pasal 2 dan 3). 
Sebagai konsekuensi logis dari adanya satu perkawinan, maka akan lahirlah beberapa hak dan kewajiban yang harus dipenuhi oleh masingmasing pasangan. Pemenuhan hak oleh laki-laki dan perempuan setara dan sebanding dengan beban kewajiban yang harus dipenuhi oleh laki-laki dan perempuan (suami dan isteri). Dengan demikian sejatinya masing-masing pasangan tidak ada yang lebih dan yang kurang dalam kadar pemenuhan hak dan pelaksanaan kewajiban. Keseimbangan dan kesetaraan dalam sebuah perkawinan, sesungguhnya sudah dimulai pada masa pra-nikah, yang oleh Islam disebut dengan "sekufu". Ditetapkannya "sekufu" yang berarti seimbang dan setara sebagai salah satu syarat untuk melangsungkan pernikahan mengindikasikan bahwa sesungguhnya modal penting dalam mewujudkan motif ideal perkawinan dengan realitas perkawinan yang dijalani oleh suami dan isteri (laki-laki dan perempuan) adalah tergantung pada adanya kesetaraan. Pada pembahasan berikut akan dijelaskan kajian kritis terhadap kesetaraan hak dan kewajiban antara suami dan isteri.

\section{B. Kesetaraan dalam Menentukan Pilihan Pasangan}

Dikalangan Ulama' terdapat perbedaan pendapat, apakah kedudukan wali merupakan syarat syah atau tidaknya suatu perkawinan. Pendapat pertama, yang didasarkan kepada riwayat dari Aisyah, mengatakan bahwa "tidak ada nikah tanpa wali" dan wali menjadi syarat syahnya suatu perkawinan. Imam Syafi'i termasuk yang berpendapat kelompok pertama ini ${ }^{5}$, dan pendapat inipula yang mayoritas dianut dan diikuti oleh kebanyakan umat Islam di Indonesia. Bahkan secara legal formal kedudukan wali ini dimasukkan dalam hukum terapan yang berlaku di lingkungan peradilan di Indonesia yang berisi:

"Wali nikah dalam perkawinan merupakan rukun yang harus dipenuhi bagi calon mempelai wanita yang bertindak untuk menikahkannya." ${ }^{\prime \prime}$

${ }^{5}$ Ibnu Rusyd, Bidayatul Mujtahid, jilid II, terjemahan Imam Ghazali Said \& Ahmad Zaidun, (Jakarta Pustaka Amani, 2007), hlm. 409.

${ }^{6}$ Lihat KHI, Pasal 19. 
Pendapat kedua, yang didukung oleh Abu Hanifah, Zufar, Asy-Syaibi dan al-Zuhri, berpendapat bahwa pernikahan dengan tidak ada wali adalah syah jika calon suami sekufu (sebanding). ${ }^{7}$

Terlepas dari adanya perdebatan tentang status wali dalam pernikahan, dalam realitas social masyarakat khususnya di Indonesia, telah mendominasi pada keyakinan kepada pendapat pertama di atas, oleh karena itu dalam pembahasan ini penting kajian yang lebih kritis terhadap hak atau kewenangan dan atau otoritas yang dimiliki oleh seorang wali yang dalam istilah fikih dikenal dengan hak "ijbâr".

Hak ijbâr yang dimiliki orang tua atau wali dalam perspektif Islam sesungguhnya tidaklah hak mutlak seperti hak veto yang keputusannya tidak boleh diganggu gugat, jika sedemikian itu yang menjadi pemahaman terhadap hak dan kewenangan seorang wali mujbir, tentulah akan bertentangan dengan prinsip 'kemerdekaan' dan kebebasan berkehendak bagi perempuan, padahal prinsip ini sungguh sungguh sangat diperhatikan dan dujunjung tinggi dalam Islam, dalam hal ini juga termasuk dalam hal memilih jodoh. Interpretasi yang kurang proporsional terhadap "hak ijbâr" ini merupakan salah satu pintu yang membuka peluang kepada orang tua atau wali untuk berlaku sewenang-wenang terhadap anak perempuan yang akan menikah. Adapun alasan yang lazim dikemukakan orang tua untuk mempergunakan hak tersebut dengan argumentasi dalam rangka memberikan yang terbaik untuk anak perempuannya.

Imam Syafi'i sebagai salah satu imam mazhab yang berpendapat adanya hak ijbâr bagi wali (orang tua), menjelaskan bahwa adanya hak ijbâr tersebut dimaksudkan untuk memberi kesempatan kepada wali untuk berbuat yang terbaik dan peduli, terhadap masa depan anaknya, termasuk dengan memilihkan jodohnya. Oleh karenanya menurut Imam Syafi'i hak ijbâr tetap memiliki rambu-rambu yang cukup tegas, terutama untuk kebahagiaan dan kemaslahatan masa depan perkawinan anaknya. ${ }^{8}$

\footnotetext{
${ }^{7}$ Ibnu Rusyd, loc.cit.

${ }^{8}$ Muhammad al-Syarbini, al-Iqna', (Surabaya: Dar al-Ihya' al-Kutub al-Arabiyyah, t.th.), hlm. 168 .
} 
Tentang hak ijbâr ini, cukup relevan untuk dicermati suatu kasus yang terjadi pada masa Nabi, sebagaimana yang terdapat dalam sebuah hadis riwayat 'A'isyah r.a., bahwa seorang gadis datang mengadu kepadanya perihal ayahnya yang memaksa kawin dengan seorang lelaki yang tidak ia sukai. Setelah disampaikan kepada Rasulullah, maka Rasulullah memutuskan untuk mengembalikan urusan perkawinan itu kepada anak gadis tadi. ${ }^{9}$ Ibnu Taimiyah juga sependapat dengan para ulama yang tidak memperbolehkan bapak memaksa anak gadisnya yang sudah dewasa untuk menikah tanpa persetujuan anak gadisnya. ${ }^{10}$

Pendapat yang sama juga dikemukakan oleh Asghar Ali Engineer yang mengatakan, bahwa di dalam al-Qur'an perempuan setara dengan laki-laki dalam kemampuan mental dan moralnya, sehingga masing-masing memiliki hak independen yang sama dalam menentukan pasangannya. ${ }^{11}$ Dalam konteks ini dia mendasarkan pada ayat al-Quar'an, surat al-Ahzab ayat 35 sebagai berikut:

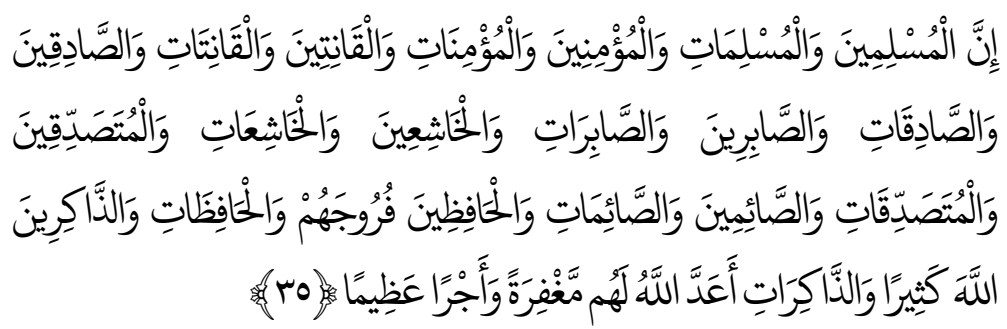

"Sesungguhnya kaum lelaki dan wanita yang tunduk, percaya pada Allah dan Rasul-Nya, melakukan ketaatan, jujur dalam perkataan, perbuatan dan niat, tabah dalam menghadapi cobaan dalam berjuang di jalan Allah, merendahkan diri, menyedekahkan sebagian harta bagi orang yang membutuhkan, melakukan puasa wajib dan sunnah, menjaga kemaluan dari hal-hal yang dilarang, serta berzikir pada Allah dengan hati dan lisan, niscaya Allah akan memberikan

\footnotetext{
${ }_{9}^{9}$ Masdar Farid Mas'udi, Islam dan Hak-Hak Reproduksi Perempuan: Dilaog Fiqih Pemberdayaan, (Bandung: Mizan, 1997), hlm. 90-91.

${ }_{10}$ Ibnu Taimiyah, Hukum-Hukum Perkawinan, Alih bahasa oleh Rusnan Yahya, (Jakarta: Pustaka al-Kausar, 1997), hlm. 124.

${ }_{11}$ Asghar Ali Engineer, op. cit., hlm. 137.
} 
pengampunan bagi segala dosa dan pahala yang besar atas perbuatan baik mereka." (QS. al-Ahzab [33]: 35)

Dari ayat di atas menurut pendapat Asghar, bahwa kesetaraan laki-laki dan perempuan yang disebutkan al-Qur'an meliputi pula kesetaraan lakilaki dan perempuan dalam kontrak perkawinan. Seorang perempuan sebagai pihak yang sederajat dengan laki-laki, yang dapat menetapkan syaratsyarat yang diinginkannya sebagaimana juga laki-laki. Laki-laki tidak lebih tinggi kedudukannya dalam hal ini. ${ }^{12} \mathrm{Hal}$ ini sangat relevan dengan ketentuan yang terdapat dalam Kompilasi Hukum Islam yaitu: "Hak dan kedudukan isteri adalah seimbang dengan hak dan kedudukan suami dalam kehidupan rumah tangga dan pergaulan hidup bersama dalam masyarakat. Masing-masing pihak berhak untuk melakukan perbuatan hukum."13

Pada hakekatnya perkawinan merupakan sebuah ikatan yang memiliki dimensi, di samping individual (hubungan masing-masing pasangan), juga dimensi sosial, yakni berkaitan dengan hubungan masing-masing pasangan dengan lingkungan keluarga atau masyarakat yang lebih luas. Dalam konteks ini, kebebasan perempuan dalam memilih pasangan sesuai dengan yang diharapkannya, tidak dimaknai tanpa harus seizin dan ridho wali. Sebab tidak dapat dipungkiri bahwa perkawinan akan lebih sempurna jika kebebasan tersebut dalam waktu yang bersamaan juga diharapkan "memuaskan" (baca diridhi dan direstui) oleh orang tua (wali) sebagai pihak yang mengakadkan dirinya dengan calon suami.

\section{Kesetaraan dalam Fungsi dan Peran.}

Perempuan dalam statusnya sebagi isteri dan ibu dari anak-anak mempunyai hak yang cukup urgen dan mendasar dalam kehidupan ruman tangganya, yakni hak untuk memperoleh jaminan kesejahteraan yang dalam terminology fikih dikenal dengan nafkah. Hal ini berkaitan dengan fungsi dan peran berat yang dipikul perempuan atau isteri sebagai pelaku reproduksi (mengandung, melahirkan, menyusui/merawat anak), yang tidak

${ }^{12}$ Asghar Ali Engineer, op. cit., hlm. 138.

${ }^{13}$ Lihat KHI Pasal 79. 
bisa dialihperankan kepada laki-laki atau suami. Di samping itu masih ada tugas-tugas kerumahtanggaan (mengelola rumah tangga, melayani suami) yang menjadi tanggungan isteri.

Masdar memandang hak isteri untuk mendapatkan nafkah dan jaminan kesejahteraan dari suami, di samping karena secara normatif telah disebutkan dalam nas (al-Qur'an dan Hadis), juga karena isteri mempunyai peran dan tanggung jawab yang cukup besar dalam reproduksi dan pengelolaan rumah tangga. ${ }^{14}$ Dengan demikian adalah tidak adil jika perempuan atau isteri dibebani pula dengan masalah pembiayaan hidup (untuk keperluan makan, tempat tinggal, pakaian, kesehatan, dan sebagainya), maka sudah selayaknya suami memikul tanggung jawab tersebut.

Nafkah atau belanja yang harus diberikan suami kepada isteri antara lain adalah untuk memenuhi kebutuhan makan, tempat tinggal, pembantu rumah tangga, pengobatan (kesehatan). Mazhab Hanafi berpendapat bahwa kewajiban nafkah suami meliputi makanan daging, sayur mayur, buahbuahan, minyak zaitun dan samin serta segala kebutuhan yang diperlukan sehari-hari dan sesuai dengan keadaan (standar) umum. Berbeda dengan mazhab Hanafi, mazhab Syafi'î menetapkan jumlah nafkah bukan diukur dengan jumlah kebutuhan, tetapi disesuaikan dengan kemampuan suami. ${ }^{15}$ Dalam hal ini sejalan dengan KHI pasal 80 sebagai berikut:

(2) Suami wajib melidungi isterinya dan memberikan segala sesuatu keperluan hidup berumahtangga sesuai dengan semampuannya

(3) Suami wajib memberikan pendidikan agama kepada isterinya dan memberi kesempatan belajar pengetahuan yang berguna dan bermanfaat bagi agama, nusa dan bangsa.

(4) sesuai dengan penghasilannya suami menanggung:

a. nafkah, kiswah dan tempat kediaman bagi isteri;

b. biaya rumah tangga, biaya perawatan dan biaya pengobatan bagi isteri dan anak;

c. biaya pendididkan bagi anak.

${ }^{14}$ Masdar Farid Mas'udi, op. cit., hlm. 76.

${ }^{15}$ Sayyid Sabiq, op. cit., hlm. 147 dan 153. 
(5) Kewajiban suami terhadap isterinya seperti tersebut pada ayat (4) huruf $a$ dan $b$ di atas mulai berlaku sesudah ada tamkin sempurna dari isterinya." 16

Prinsip mendasar dalam menetapkan kewajiban suami memberi nafkah kepada isterinya adalah dalam rangka menjaga anggota keluarga terbebas dari keterlantaran. Sehingga dalam soal jumlah nafkah yang harus diberikan penulis cenderung kepada pendapat yang mengatakan bahwa hal itu sangat tergantung kepada kebutuhan rumah tangga (isteri dan anakanak) di satu pihak dan kemampuan suami di lain pihak. Akan tetapi, jika sampai keluarga terlantar karena suami tidak memperhatikan kewajiban nafkahnya, isteri dapat mengajukan gugatan cerai (jika keadaan benar-benar memaksanya). ${ }^{17}$

Persoalan nafkah bagi suami yang tidak mampu adalah pertimbangan kemanusiaan, dan kondisi itu dapat dimungkinan terjadi kepada siapapun. Oleh karena itu dalam situasi dan kondisi suami tidak dapat memenuhi nafkah keluarganya maka isteri dapat membebaskan suami dari kewajiban nafkah ini seperti dijelaskan dalam ayat 6 pasal $80 \mathrm{KHI}$. "Isteri dapat membebaskan suaminya dari kewajiban terhadap dirinya sebagaimana tersebut pada ayat (4) huruf a dan b." 18

Menurut Nasaruddin Umar, Islam mewajibkan laki-laki sebagai suami untuk memenuhi kebutuhan isteri dan anak anaknya. Tetapi ini bukan berarti perempuan sebagai isteri tidak berkewajiban -secara moral $-{ }^{19}$ membantu suaminya mencari nafkah. Dia mencontohkan bahwa pada masa Nabi Muhammad SAW., dan sahabatnya, sekian banyak perempuan (isteri) yang bekerja. Ada yang bekerja sebagai perias pengantin, seperti

${ }^{16}$ Lihat KHI, Pasal 80, ayat 2-5.

${ }^{17}$ Lihat: Pasal 77 ayat $6 \mathrm{KHI}$ berikut: jika suami atau isteri melalaikan kewjibannya masing-masing dapat mengajukan gugatan kepada Pengadilan Agama.

18 Yang dimaksud dengan huruf a dan $b$ adalah: a. nafkah, kiswah dan tempat kediaman bagi isteri; $b$. biaya rumah tangga, biaya perawatan dan biaya pengobatan bagi isteri dan anak. (ibid.)

${ }^{19}$ Kewajiban isteri untuk memenuhi nafkah keluarga menurut Nasaruddin dalam hal ini hanyalah kewajiban secara moral, bukan kewajiban hukum sebagaimana yang dibebankan kepada suami. 
Ummu Satim binti Malhan, bahkan isteri Nabi Muhammad SAW. Zainab binti Zahesy juga aktif bekerja sampai pada menyimak kulit binatang, dan hasilnya itu beliau bersedekah. Demikian juga Raithah, isteri dari sahabat Nabi yang bernama Abdullah Ibnu Mas'ud, sangat aktif bekerja, karena suami dan anaknya ketika itu, tidak mampu mencukupi kebutuhan hidup keluarga ini. ${ }^{20}$

Namun dalam penerapan pasal 80 ayat $6 \mathrm{KHI}$ di atas, menurut penulis harus benar-benar selektif, sebab pandangan minimalis tersebut rawan terhadap manipulasi. Adalah sangat mungkin terjadi, alasan ketidakmampuan suami dijadikan oleh suami yang tidak bertanggung jawab untuk tidak berusaha, atau bahkan dijadikan suami sebagai alasan mempekerjakan isteri disektor produksi (pekerjaan yang menghasilkan materi). Sehingga pada akhirnya isteri di samping harus menanggung beban reproduksi dan kerumahtanggaan, juga masih menanggung beban produksi yang tidak mampu dilakukan oleh suami. Sehingga perempuan tersebut memiliki peran ganda. Akan tetapi yang menjadi titik tekan di sini adalah bahwa peran ganda seorang isteri tidak wajib hukumnya. Walaupun hal itu diperbolehkan dalam pandangan agama. Dengan demikian suami memiliki kewajiban nafkah, seberapa pun dia mampu.

Tidak wajibnya isteri menanggung nafkah, selain tanggung jawab berat yang sudah diembannya dalam bidang reproduksi juga karena akan berpotensi besar timbulnya ekses ekses negetif yang sedimikian kompleks sebagai implikasi beralihnya peran perempuan dari reproduksi dan domestik ke sektor produksi dan publik. Secara intern keluarga, kondisi demikian akan berpengaruh terhadap konsentrasi perempuan dalam mengelola pekerjaan kerumah-tanggaan termasuk dalam hal pengasuhan terhadap anak. Belum lagi jika dikaitkan dengan problem sosial wanita pekerja, dimana banyak perempuan yang berhadapan dengan berbagai problematika perburuhan misalnya, upah yang rendah, konflik dengan majikan, pelecehan, pemerkosaan dan sebagainya. Dan secara individual, keterlibatan perempu-

20 Nasaruddin Umar, Argumen Kesetaraan Jender Perspektif al-Qur'an, (Jakarta, Paramadina, 1999), hlm. xxxiv-xxxv. 
an di sektor kerja akan -di samping menambah beban- secara otomatis mengurangai waktu istirahat perempuan dan aktivitas-aktivitas individual lainnya seperti untuk pengembangan dan aktualisasi diri dalam kegiatan siosial. $^{21}$

\section{Kesetaraan dalam Menikmati Hubungan Seksual}

Dalam perkawinan, terdapat ajaran-ajaran tentang hak dan kewajiban antara suami dan isteri. Suami memiliki hak dan kewajiban atas isterinya, demikian pula isteri, memiliki hak dan kewajiban terhadap suami. Nafkah misalnya sebagimana telah dijelaskan sebelumya, merupakan kewajiban yang harus dibayar suami yang karena hal itu adalah hak isteri. Sedangkan sebagai imbangan dari kewajiban yang telah dilakukan suami, isteri berkewajiban taat dan hormat kepada suami (termasuk di dalamnya adalah menjaga kehormatan dan harta suami serta minta ijin jika ingin keluar dari rumah).

Perbincangan tentang hak dan kewajiban suami isteri tidak terlepas dari perbincangan tentang bagaimana masing-masing ber-mu'âsyarah secara ma'rûf, saling menggauli dengan baik secara objektif. Karena itu hak dan kewajiban suami isteri diletakkan dalam bingkai mu'âsyarah bi al-ma'rûf. Termasuk dalam persoalan hak dan kewajiban suami isteri adalah dalam soal hubungan seks suami isteri. Sehingga secara normatif, Kesetraan dalam hubungan seks suami isteri adalah bagian yang tidak terpisahkan dari implementasi dan prwujudan dari konsep mu'âsyarah bi al-ma'rûf. Hanya

${ }^{21}$ Ken Suratiyah menggambarkan problematika perempuan pekerja sebagai berikut: Bagaimana pun juga, bekerja tidaklah merubah status wanita dan tidak berarti mengurangi tanggung jawab istri terhadap pekerjaan rumah tangga sehari-hari. Ketika ibu sedang mencari nafkah, tidak ada anggota keluarga yang bisa menggantikan tugastugas kerumah tanggaannya walau pun ada suami. Ibu akan menunda dulu kegiatan kerumahtanggaannya sampai usai mencari nafkah. Atau sebaliknya kegiatan rumah tangga harus dia selesaikan sebelum kegiatan mencari nafkah dimulai, sehingga ibu harus bangun lebih pagi. Padatnya kegiatan-kegiatan itu membuat wanita mengorbankan waktu untuk kegiatan individual dan istirahatnya. Mereka mengabaikan kesehatannya, tidak mempunyai waktu untuk meningkatkan kemampuan diri, sehingga wanita semakin jauh tertinggal. Ken Suratiyah, "Pengorbanan Wanita Pekerja Industri", dalam Irwan Abdullah (Ed), Sangkan Paran Gender, (Yogyakarta: Pusat Penelitian Kependudukan UGM, 1997), hlm. 231. 
saja yang menjadi persoalan adalah, apakah dalam soal hubungan seks, suami isteri dalam posisi sama dan sederajat? Ataukah isteri yang cenderung sebagai objek karena itu adalah kewajiban yang harus dia lakukan sebagai isteri dan menjadi hak suami?

Dalam soal hubungan seks suami isteri, pandangan tentang status keduanya dipengaruhi oleh konsep dasar perkawinan itu sendiri. Jika sebuah perkawinan didefinisikan sebagai aqad tamlik (kontrak pemilikan), yakni bahwa dengan pernikahan seorang suami telah melakukan kontrak pembelian perangkat seks (bud'u) sebagai alat melanjutkan keturunan, dari pihak perempuan yang dinikahinya. Dalam konsep pernikahan yang seperti ini, pihak laki-laki adalah pemilik sekaligus penguasa perangkat seks yang ada pada tubuh isteri. Dengan begitu, kapan, di mana, dan bagaimana hubungan seks dilakukan, sepenuhnya tergantung kepada pihak suami, dan isteri tidak punya pilihan lain kecuali melayani.

Akan tetapi, jika perkawinan didefinisikan sebagai akad ibâhah (kontrak untuk membolehkan sesuatu dalam hal ini alat seks yang semula dilarang), artinya dengan perkawinan itu alat seks perempuan tetap merupakan milik perempuan yang dinikahi, hanya saja kini alat tersebut sudah menjadi halal untuk dinikmati oleh seseorang yang telah menjadi suaminya. Dengan demikian, kapan hubungan seks akan dilaksanakan, dengan cara bagaimana dilakukan, tidak semata-mata tergantung kepada kehendak suami, melainkan atas kehendak bersama dari kedua belah pihak, yakni suami dan isteri, baik waktu maupun caranya. ${ }^{22}$

Terdapat kecenderungan umum di masyarakat, bahwa hubungan seksual suami isteri, yang lebih banyak menikmatinya adalah suami. Sementara pihak isteri hanya melayani, sesuatu yang telah melekat dalam predikatnya sebagai isteri, pelayan dan pemuas suami, sehingga isteri dalam melakukan hubungan seks dengan suami, semata-mata menjalankan kewajiban. Hal itu dipengaruhi oleh pandangan yang dianut kalangan ahli

${ }^{22}$ Lihat Husein Muhammad, Pandangan Islam tentang seksualitas, dikutip dari Abdurrahman al-Jazairi, al-Figh 'alâ Mazâhib al-Arba'ah, IV, (Istanbul: Dar ad-Da'wah, t.th.), hlm. 1-3. 
fiqih, yang mengatakan bahwa hubungan seks bagi isteri adalah sematamata kewajiban.

Menurut Masdar, pemahaman terhadap seksualitas ini terkait dengan pandangan konvensional yang dianut oleh kebanyakan masyarakat tradisional-agraris, bahwa seks adalah barang suci, yakni menjamin keturunan (procreation). Hanya kalangan masyarakat kota yang mulai berpandangan bahwa seks, juga bagi kaum perempuan, adalah perangkat biologis yang dianugrahkan Tuhan untuk kenikmatan (pleasure). Dalam sebuah hadis secara eksplisit sebenarnya diakui bahwa hubunagn seks bukan semata untuk tujuan keturunan akan tetapi juga untuk kenikmatan. Yakni ketika seorang yang hendak kembali kepada suami lama yang telah mentalaqnya tiga kali (talaq ba'in), Rasulullah bersabda:"Jangan, kamu tidak boleh kembali ke suami yang telah mem-bai'in-mu sebelum kamu kawin dengan suami lain dan kamu sendiri merasakan madunya sebagaimana ia juga telah merasakan madumu. "Dari teks hadis ini, menggunakan istilah "madu" dengan jelas yang dimaksud merasakan madu bukan saja telah terjadinya hubungan seks antara keduanya, tapi harus menikmati hubungan tersebut, seperti halnya menikmati manisnya madu. ${ }^{23}$

Pendapat yang sama juga dikemukakan oleh Siti Ruhaini Dzuhayati, salah satu feminis Indonesia, menilai bahwa tiadanya hak seksualitas perempuan adalah akibat rumusan hukum Islam yang termaktub dalam berbagai kitab Fiqih produk abad pertengahan yang dirumuskan berdasarkan kaca mata laki-laki. Dasar yang dipakai dalam fiqih itu, kata Ruhaini, itu adalah bahwa hubungan suami isteri memiliki dimensi ibadah. Namun, Ruhaini berpendapat, ibadah harus dilaksanakan secara ikhlas tanpa keterpaksaan. Karena hubungan seksual bukan sekedar hubungan yang bersifat fisik maka nilai ibadahnya juga harus ditentukan oleh keikhlasan yang bersifat psikologis. ${ }^{24}$ Sehingga aplikasi konsep mu'âsyarah bi al-ma'rûf dalam

${ }^{23}$ Masdar Farid Mas'udi, op. cit., hlm. 107 dan 203.

${ }^{24}$ Siti Ruhaini Dzuhayatin, "Marital Rape, Bahasan Awal dari Perspektif Islam,dalam Eko Prasetyo \& Suparman Marzuki (Ed.), Perempuan dalam Wacana Perkosaan, (Yogyakarta: PKBI Yogyakarta, 1997), hlm. 93. 
hubungan seksual suami-isteri adalah kebaikan objektif dalam pandangan mereka berdua. Tidak cukup hanya baik menurut orang lain, para teoritisi (ulama fiqih), atau pihak suami saja. Tetapi harus baik bagi suami isteri sebagai satu pasangan yang menurut al-Qur'an setara. Dalam hal ini, asySyirazi mengatakan, meskipun pada dasarnya isteri wajib melayani permintaan suami, akan tetapi jika dia memang tidak terangsang untuk melayaninya, ia boleh menawar atau menangguhkan sampai batas tiga hari. Demikian juga bagi isteri yang sedang sakit, maka tidak wajib baginya untuk melayani ajakan suami sampai sakitnya hilang. ${ }^{25}$ Jika suami tetap memaksa pada hakekatnya dia telah melanggar prinsip mu'âsyarah bi alma'rûf dengan berbuat aniaya kepada pihak yang justru seharusnya dia lindungi dengan kapasitas sebagai suami.

Perempuan sebagaimana juga laki-laki memiliki keinginan dan hasrat untuk dapat menikmati sebuah hubungan badan (seksual) dengan masingmasing pasangannya. Para spikonanalisis menganggap bahwa seksualitas merupakan sesuatu yang otonom di mana setiap individu memiliki hak terhadap pemuasannya. ${ }^{26}$ Bahkan ajaran agama memandang itu sebagai hal yang manusiawi dan -tentu- perlu disalurkan lewat jalan yang sah yakni sebuah perkawinan, sehingga dalam perkawinan kepuasan seksual tidak hanya dimonopoli laki-laki.

Nafkah bagi isteri tidak hanya sebatas nafkah lahiriyah (makan, pakaian, tempat tinggal, jaminan kesehatan dan lain-lain), tetapi meliputi juga nafkah batin (menggauli, berhubungan seks, bisa juga perhatian dan kasih sayang). Sehingga jika ditelusuri lebih jauh dalam persoalan nafkah isteri, maka adalah kewajiban suami untuk melakukan hubungan seks dengan isteri sampai pada batas isteri dapat terpuaskan (menikmati)nya. Masdar bahkan sampai berpendapat, jika suami tidak bersedia menunaikan kewajiban nafkahnya kepada isteri (nafkah batin) dan isteri tidak mau menerimanya, maka isteri berhak mengajukan hal itu ke pangadilan dan peng-

${ }^{25}$ al-Syirazi, al-Muhazzab, (Beirut: Dar al-Fikr, t.th.), II, hlm. 65

${ }^{26}$ Siti Ruhaini Dzuhayatin, op. cit., hlm. 86. 
adilan pun bisa mempertimbangkan tindakan yang lebih bisa menjamin keadilan, dalam hal ini bagi pihak isteri. ${ }^{27}$

Kisah Usman bin Ma'dum adalah merupakan momentum sejarah betapa pentingnya kesetaraan dalam pemuasan seksual. Usman bin Ma'dum sebagaimana dikisahkan dalam sejarah adalah seorang suami yang berlebihan dalam beribadah, sehingga mengharamkan tidur pada malam hari dengan isterinya. Bahkan dia sendiri ingin mengebiri alat kelaminnya supaya konsentrasi dalam beribadah. Maka ketika isterinya yang bernama Basila mengadukan perihal tersebut kepada Nabi Muhammad SAW. Kemudian Nabi memanggil Usman bin Ma'dum lalu berkata: Celaka engkau wahai Usman! Aku Perintahkan supaya engkau meninggalkan sikap yang keliru itu. Pulanglah berbukalah (puasa) dan pergaulilah isterimu seperti biasa. ${ }^{28}$

\section{E. Kesetaraan dalam Menentukan Rekayasa Genetika}

Mendapatkan keturunan atau anak adalah menjadi harapan dan kebanggaan yang bersifat naluriyah bagi setiap manusia yang diikhtiari dengan jalan pernikahan. Agama Islam memberikan keutamaan yang tinggi bagi kedua orang tua yang mempunyai anak anak shalih dan shalihah, karena do'a dari mereka akan menjadi amal jariyah bagi kedua orang tuanya yang tidak pernah ada putus-putusnya. Bahkan sebelum datangnya Islam pada zaman Jahiliyyah, anak menjadi kebanggaan bagi orang tua (khususnya anak laki-laki), dan setelah Islam datang orang Arab masih suka menyombongkan diri dengan harta dan anak yang banyak, hal ini sebagaimana tersirat dalam al-Qur'an surat al-Saba' ayat: 35 .

\footnotetext{
${ }^{27}$ Menurut Ahmad bin Hanbal bahwa batas maksimal pemenuhan hasrat itu empat bulan. Jika tidak ada halangan serius, minimal setiap empat bulan satu kali hubungan dengan istri harus dilakukan. Sementara menurut sebuah riwayat dari ‘Umar Ibn Khattab, batas maksimal adalah emam bulan. Akan tetapi batasan-batasan yang dilakukan baik oleh Ahmad bin Hanbal maupun dalam riwayat 'Umar, sebaiknya batasan tersebut lebih fleksibel. Akan lebih baik jika ukuran batasannya adalah ketika istri sudah tidak mampu menahan hasratnya, bisa empat bulan atau bisa lebih kurang dari itu. Sangat tergantung dengan kondisi masing-masing istri. Masdar Farid Mas'udi, op. cit., hlm. 115-116.

28 A. Rahmat Rosyadi, Islam Problem Sex Kehamilan dan Melahirkan, (Bandung, Angkasa, 1993), hlm. 21.
} 
Akan tetapi, dengan pertimbangan-pertimbangan tertentu, ada sebagian pasangan suami isteri yang harus memilih untuk menunda kehamilan/kelahiran anak. Lajimnya cara yang ditempuh adalah dalam melakukan hubungan seksual menggunakan alat pencegah kehamilan (kontrasepsi). Dalam menentukan siapakah yang berhak memutuskan untuk melakukan atau tidak rekayasa keturunan (anak) itu, sejatinya juga harus setara antara laki-laki dan perempuan (suami dan isteri).

Menurut Syaikh Mahmûd Syaltut, untuk mementukan siapa yang berhak memutuskan unutk melakukan rekayasa genetika ini setidaknya ada empat pendapat. Pertama, pendapat yang dikemukakan oleh al-Ghazali dari kalangan mazhab Syafi'i, mengatakan bahwa yang berhak memutuskan untuk punya anak (lagi) atau tidak adalah suami/ayah. Konsekuensinya, jika suami menghendaki anak, isteri tidak berhak apa-apa selain menuruti kemauannya. Pendapat seperti ini diadasarkan pada QS. al-Baqarah ayat 233 yang menyebut anak sebagai milik bapak, sebagai berikut:

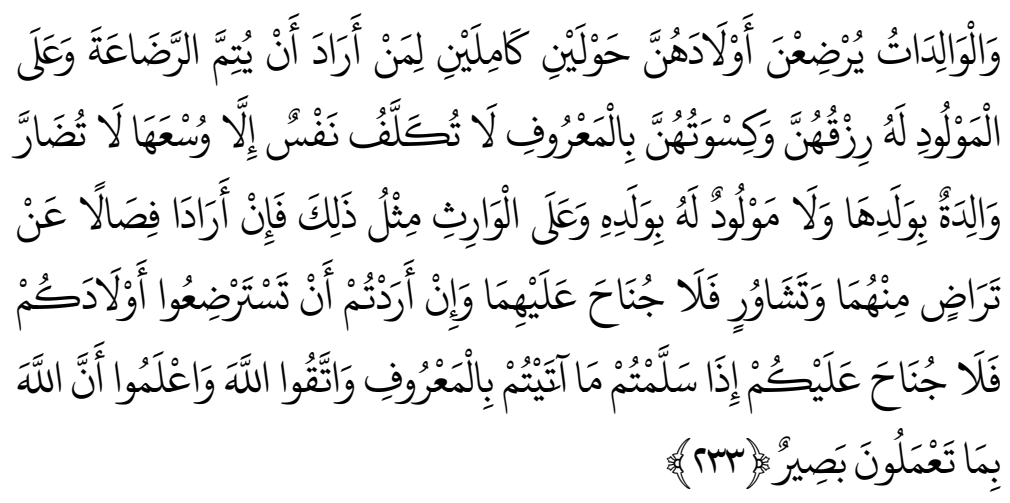

"Tbu berkewajiban menyusui anaknya selama dua tahun penuh demi menjaga kemaslahatan anak, kalau salah satu atau kedua orangtua ingin menyempurnakan penyusuan karena anaknya membutuhkan hal itu. Dan ayah berkewajiban -karena sang anak adalah keturunan ayah- untuk memberikan nafkah kepada sang ibu dengan memberikan makan dan pakaian sesuai dengan kemampuannya, tidak boros dan tidak pula terlalu sedikit. Karena manusia tidak diwajibkan apa pun kecuali sesuai dengan kemampuannya. Nafkah itu hendaknya tidak merugikan sang ibu, dengan mengurangi hak nafkahnya 
atau dalam mengasuh anaknya. Begitu juga sang anak tidak boleh menyebabkan kerugian ayahnya dengan membebaninya di atas kemampuannya, atau mengurangi hak ayah pada anak. Apabila sang ayah wafat atau jatuh miskin sehingga tidak mampu mencari penghidupan, maka kewajiban memberi nafkah dilimpahkan kepada pewaris anak jika ia memiliki harta. Apabila salah satu atau kedua orangtua menginginkan untuk menyapih anak sebelum dua tahun secara sukarela dan dengan melihat maslahat anak, maka hal itu dibolehkan. Kalau sang ayah hendak menyusukan anak kepada wanita lain, hal itu juga dibolehkan. Dalam hal ini, orang tua harus membayar upah dengan rida dan cara yang baik. Jadikanlah Allah sebagai pengawas dalam segala perbuatanmu. Dan ketahuilah bahwa Allah Mahaperiksa perbuatan itu dan akan memberikan balasannya. (QS. al-Baqarah [2]: 233)

Kedua, pendapat yang banyak dianut oleh ulama Hanafiah mengatakan bahwa yang berhak menentukan apakah akan mempunyai anak atau tidak adalah keduanya, suami dan isteri. Dasarnya adalah bahwa soal anak tidak mungkin terwujud tanpa partisipasi dari kedua belah pihak. Asal usulnya pun berakar dari sperma suami dan ovum isteri. Hadis Rasulullah yang mewajibkan anak untuk melipatgandakan baktinya kepada kedua orang tua, bahkan terutama ibu, bisa menguatkan pendapat ini. Dengan demikian untuk memutuskan apakah akan punya anak atau tidak, harus didasarkan pada kehendak dan persetujuan bersama anatara suami dan isteri.

Ketiga, bahwa menentukan keturunan bukan hanya hak suami isteri, melainkan juga umat/masyarakat dengan penekanan kepada keputusan suami isteri. Kalangan ulama Hambali dan sebagian ulama Syafi'iyah menganut pendapat seperti ini. Artinya, kebutuhan akan kemaslahatan masyarakat perlu diperhitungkan bagi pasangan suami isteri untuk menentukan apakah akan menempuh rekayasa genetika.

Keempat, yang banyak dianut oleh ahli hadis, hampir sama dengan pendapat ketiga, tetapi dengan lebih menekankan kepada pertimbangan kemaslahatan umat/masyarakat. Artinya, meskipun pasangan suami isteri menghendaki atau tidak keturunan/anak akan tetapi apabila kemaslahatan 
umum memutuskan lain, maka yang harus prioritaskan adalah kemaslahatan umum tersebut. ${ }^{29}$

Berangkat dari keempat pendapat di atas, tampak bahawa pendapat kedualah yang lebih relevan dengan asas kesetaraan antara suami dan isteri. Dalam arti bahwa urusan kelahiran adalah semata-mata urusan keluarga (suami isteri), lebih khusus lagi adalah urusan isteri, karena dialah yang pihak yang paling bersangkutan dengan masalah kehamilan dan kelahiran.

\section{F. Kesetaraan dalam Pengasuhan Anak}

Sebagai implikasi dari peran ganda yang diperankan oleh seorang isteri, selanjutnya muncul pertanyaan mendasar yaitu; siapa yang berkewajiban penuh dalam perawatan anak? Apakah seorang isteri (ibu), yang dalam pandangan stereotype adalah makhluk domestik, sehingga urusan rumah tangga termasuk merawat anak adalah kewajibannya; atau ada pada suami (ayah), yang secara normatif dipandang al-Qur'an sebagai pemilik anak; dan atau kedua-duanya, sebagai tanggung jawab kolektif di dalam rumah tangga.

Imam malik berpendapat, kewajiban menyusui anak bagi ibu lebih merupakan kewajiban moral (panggilan hati nurani) dari pada kewajiban formal (legal). Artinya kalau ibu tidak mau melakukanya, suami atau pengadilan sekalipun tidak berhak untuk memaksanya. Senada dengan imam Malik, para ulama dari kalangan mazhab Hanafi, Syafi'i, Hambali dan sebagian pengikut Maliki berpendapat, bahwa menyusui anak oleh sang ibu itu hanya bersifat mandub (sebaiknya). Kecuali kalau si anak menolak susuan selain susu ibu, atau ayah tidak sanggup membayar upah ibu susuan, maka menjadi wajib bagi ibu untuk menyusuinya. ${ }^{30}$

Ketentuan formal fiqih yang "membebaskan' ibu dari kewajiban menyusui, lebih dimaknainya sebagai penghormatan yang begitu tinggi terhadap ibu, yang secara empiris menanggung beban reproduksi yang begitu berat. Walaupun dalam realitas di tengah masyarakat tidak memungkinkan,

\footnotetext{
${ }^{29}$ Masdar Farid Mas'udi, op. cit., hlm. 124-125.

${ }^{30}$ Wahbah al-Zuhaili, al-Figh al-Islâmy wa Adilatuhu, (Damaskus: Dar al- Fikr, 1989), hlm. 699 .
} 
seorang ibu tega untuk tidak menyusui anaknya selama dia mampu. Oleh karena itu yang menjadi stressing point di sini adalah, bahwa beban perawatan anak dibebankan secara kolektif antara ibu dan ayah. Jangan sampai satu pihak merasa lebih diberatkan daripada yang lainnya. Ibu karena secara kodrati mempunyai kemampuan untuk menyusui, maka tugas itu dapat diambil alih oleh ibu, sementara ayah harus mengambil alih tugas-tugas perawatan yang lain. Jadi tidak semua dikerjakan oleh ibu sementara ayah tidak mau tahu dengan alasan apapun. ${ }^{31}$

Dalam keadaan keluarga masih utuh (tidak terjadi perceraian), sistem pembagian kerja yang proporsional antara suami dan isteri sebagai dijelaskan sebelumnya sesungguhnya dapat dilaksanakan walaupun tidak bisa dipungkiri akan berhadapan dengan banyak hambatan dan kesulitan.Tetapi akan lebih sulit dan lebih problematis lagi jika kondisi ini berhadapan dengan keluarga yang mengalami perceraian, dimana seorang ayah berpisah dengan isterinya. Tentang masalah ini dalam KHI dijelaskan bahwa:

"Dalam hal terjadinya perceraian: (a) Pemeliharaan anak yang belum mumayyiz atau belum berumur 12 tahun adalah hak ibunya; (b) Pemeliharaan anak yang sudah mumayyiz diserahkan kepada anak untuk memilih diantara ayah atau ibunya sebagai pemegang hak pemeliharaanya; (c) biaya pemeliharaan ditanggung oleh ayahnya. ${ }^{32}$

Dalam kasus demikian, ibu memiliki hak prioritas dalam merawat anak. Alasannya adalah, pertama, karena sebagi ibu ikatan batin dan kasih

${ }^{31}$ Bandingkan dengan pendapat Amina Wadud Muhsin: Dalam keluarga yang suami dan istri keduanya sama-sama menanggung beban mencari nafkah guna mencukupi kebutuhan keluarga, adalah tidak adil jika hanya wanita saja yang harus mengurus semua pekerjaan rumah. Jika wanita berusaha meningkatkan amal salehnya, maka terdapat kesempatan serupa bagi kaum pria untuk meningkatkan partisipasinya lebih banyak lewat pekerjaan rumah dan mengasuh anak. Di samping itu sistem penilaian al-Qur'an terhadap amal saleh tidak memandang apakah laki-laki atau perempuan yang melakukannya: "Barangsiapa yang mengerjakan amal saleh baik ia laki-laki atau perempuan sedang ia orang beriman, maka mereka itu masuk surga (QS. 44: 124) Sistem kerjasama yang fleksibel, terpadu dan dinamis dari kerjasama saling menguntungkan seperti itu amat sangat bermanfaat dalam berbagai ragam masyarakat dan keluarga. Amina W.Muhsin, Wanita di dalam al-Qur'an, Terjemahan, Yaziar Radianti, (Bandung, Pustaka,1994), hlm. 121-122

${ }^{32}$ KHI, Pasal 105. 
sayang dengan anak cenderung selalu melebihi kasih sayang dari ayah. Kedua, derita keterpisahan seorang ibu dengan anaknya akan terasa lebih berat dibanding derita keterpisahan seorang ayah. Ketiga, sentuhan tangan keibuan yang lazimnya dimiliki oleh ibu akan lebih menjamin pertumbuhan mentalitas anak secara lebih sehat. Tentang biaya perawatan, yang terdiri atas makanan, pakaian, obat-obatan, dan kebutuhan-kebutuhan lain, termasuk di dalamnya biaya pembantu dalam merawat anak dan biaya pendidikan tetap menjadi tanggung jawab ayah.

Dampak positif dari prinsip kesetaraan seperti di atas antara lain adalah terbukanya kesempatan bagi perempuan (isteri) untuk mengembangkan potensinya lewat kiprahnya dalam kehidupan sosial. Apakah di bidang sosial, ekonomi, keagamaan, politik, budaya dan bidang-bidang lainnya. Sehingga budaya (mitos) yang mengatakan bahwa perempuan adalah makhluk domestik yang hanya dalam dinding rumahnya, bahkan tidak jarang hanya sebatas ruang-ruang dapur dan kamar tidurnya akan mendapat pencerahan.

\section{G. Hak dalam Memutuskan Perkawinan (Talaq/cerai)}

Perkawinan menurut hukum Islam, yaitu akad yang sangat kuat atau mitssâqan ghalîdzan untuk mentaati perintah Allah dan melaksanakannya merupakan ibadah. Perkawinan bertujuan untuk mewujudkan kehidupan rumah tangga yang sakinah, mawaddah, dan rahmah. ${ }^{33}$ Oleh karena itu Islam sangat tidak menyukai perceraian. Secara moral perceraian adalah sebuah pengingkaran. Akan tetapi disadari bahwa tidak mungkin perceraian sama sekali dihindari dalam kehidupan yang nisbi ini, karena itu alasan yang sangat khusus, Islam terpaksa menerima kemungkinan terjadinya perceraian.

Jadi, perceraian haruslah dipahami sebagai suatu peristiwa yang betulbetul terpaksa, ketika sudah tidak ada jalan lain yang dapat ditempuh. Mengingat perkawinan yang bukan sebagai sesuatu yang remeh, sehingga pemutusannya pun dalam keadaan-keadaan yang luar biasa. Al-Qur'an

${ }^{33}$ Lihat KHI, Pasal 2 dan 3. 
sendiri mendorong agar perceraian tidak dilakukan. ${ }^{34}$ Oleh karenanya perceraian merupakan pilihan hukum antara pasangan yang setelah mereka tidak bisa menyatukan perbedaan yang timbul antara keduanya. ${ }^{35}$

Karena pada dasarnya Islam memandang perceraian sebagai keburukan, maka hanya demi menghindari keburukan yang lebih besar perceraian bisa diizinkan - dengan penuh penyesalan. Alasan alasan yang dapat menjadi pertimbangan hakim untuk memutuskan suatu pernikahan antara lain:

1. Salah satu pihak berbuat zina atau menjadi pemabuk, pemadat, penjudi dan lain sebagainya yang sukar disembuhkan

2. Salah satu pihak meninggalkan pihak lain selama 2 (dua) tahun berturut-turut tanpa izin pihak lain dan tanpa alasan yang sah atau karena hal lain diluar kemampuannya.

3. Salah satu pihak mendapat hukuman penjara 5 (lima) tahun atau hukuman yang lebih berat setelah perkawinan berlangsung.

4. Salah satu pihak melakukan kekejaman atau penganiayaan berat yang membahayakan pihak lain.

5. Salah satu pihak mendapat cacat badan atau penyakit dengan akibat tidak dapat menjalankan kewajibannya sebagai suami atau isteri.

6. Antara suami dan isteri terus menerus terjadi perselisihan dan pertengkaran dan tidak ada harapan akan hidup rukun lagi dalam rumah tangga.

7. Suami melanggar taklik talak.

8. Peralihan agama atau murtad yang menyebabkan terjadinya ketidak rukunan dalam rumah tangga. ${ }^{36}$

Untuk mencapai tarap perceraian, sepasang suami-isteri harus melewati tahapan-tahapan rekonsiliasi dan arbitrasi. Sehingga keputusan perceraian betul-betul melewati seleksi objektivitas yang cukup ketat. Bukan sebuah keputusan yang tergesa-gesa, apalagi dalam kondisi yang masih

\footnotetext{
${ }^{34}$ Lihat, al-Qur'an, surat al-Ahzab ayat, 37: “Dan (ingatlah) ketika kamu berkata kepada orang yang Allah telah melimpahkan nikmat kepadanya, dan kamu (juga) telah memberikan nikmat kepadanya: Pertahankanlah terus istrimu dan bertaqwalah kepada Allah."

${ }^{35}$ Amina W. Muhsin, op. cit., hlm. 106.

${ }^{36}$ Lihat KHI, Pasal 116.
} 
emosional. Menurut Masdar Farid Mas'udi ada beberapa tahapan-tahapan rekonsiliasi sebagai berikut:

Pertama, masing-masing dianjurkan berintropeksi untuk melihat kelemahannya sendiri dan pada saat yang sama mengakui kelebihan pihak lain (pasangannya). Kalau dipandang perlu, pada masa intropeksi ini bisa dilakukan dengan pisah ranjang sementara (al-tahjîr fi al-madhâji) antara suami dan isteri.

Kedua, Jika langkah intropeksi dan rekonsiliasi seperti yang pertama tidak membuahkan hasil, maka dianjurkan menempuh tahapan kedua yakni arbitrasi. Yakni masing-masing pihak dianjurkan mencari jalan islah, pemulihan hubungan damai, kalau perlu dengan melibatkan atau menunjuk penengah dari masing-masing pihak.

Ketiga, Jika langkah arbitrasi juga belum berhasil, al-Qur'an sendiri mengatakan untuk terus berikhtiar, sebisa mungkin ditempuh jalan rekosnsiliasi dan arbitrasi terus dan terus. Jika sudah betul-betul buntu, barulah diputuskan untuk mengadakan perceraian.

Dalam Pasal $116 \mathrm{KHI}$ secera tegas dinyatakan bahwa, perceraian hanya dapat dilakukan di depan sidang Pengadilan Agama setelah Pengadilan Agama tersebut berusaha dan tidak berhasil mendamaikan kedua belah pihak. $^{37}$

Dalam sudut pandang fiqih, perceraian atau talaq adalah hak laki-laki. Hal itu didasarkan pada firman Allah dalam QS. al-Thalaq ayat 1:

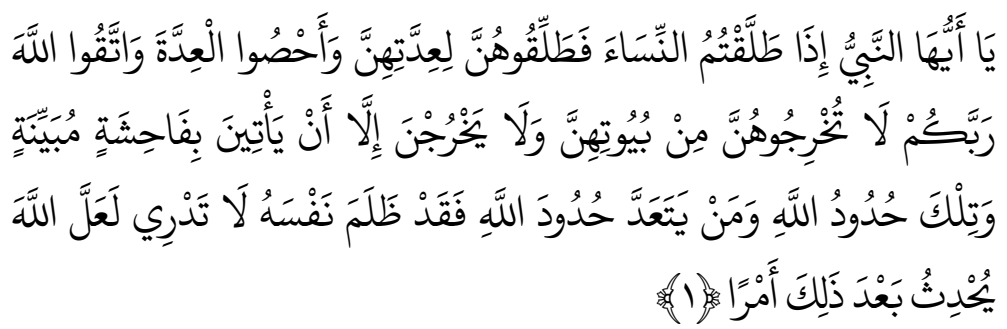

${ }^{37}$ Lihat KHI, Pasal 115 
"Wahai Nabi, jika kamu hendak menjatuhkan talak kepada istriistrimu maka jatuhkanlah talak itu ketika mereka sedang dalam keadaan suci yang tidak dicampuri. Tepatkanlah hitungan masa idah dan bertakwalah kepada Tuhanmu. Jangan izinkan istri-istri yang kamu jatuhi talak itu keluar dari tempat mereka ditalak. Jangan izinkan mereka keluar kecuali jika melakukan perbuatan keji yang sangat nyata. Ketentuan- ketentuan itu merupakan hukum yang telah ditetapkan oleh Allah untuk para hamba-Nya. Barangsiapa yang melanggar ketentuan Allah maka sesungguhnya ia telah menzalimi diri sendiri. Kamu, hai orang yang melanggar, tidak mengetahui barangkali Allah akan mewujudkan sesuatu yang tidak diperkirakan, sesudah talak itu, sehingga kedua pasangan suami-istri itu kembali saling mencintai." (QS. al-Thalaq [65]: 1)

Dari ayat di atas tampak bahwa al-Qur'an lebih menekankan aspek kesadaran moral dengan fiqih yang berada dalam wilayah legal-formal. Dalam konteks perceraian fiqih hampir tidak pernah menjelaskan proses mediasi agar perceraian bisa dihindari semaksimal mungkin. Pada aspek ini tampak karakteristik fiqih yang lebih menekankan pada aspek formalobjektif, sementara kondisi 'keterpaksaan bagi suatu perceraian, adalah suatu yang bersifat subjektif. Umumnya literatur fiqih, ketika membicarakan masalah cerai langsung yang dibicarakan adalah dimensi-dimensi teknis dan prosedural, atau lebih jauh tentang implikasi-implikasi (hukum) yang ditimbulkannya.

Dalam lintasan sejarah perkembangan hukum Islam tentang talak, ditemukan nuktah merah bahwa hak talak bukan hak mutlak bagi laki-laki (suami) ansich. Segera setelah mengentaskan kaum perempuan dari status objek mutlak keputusan laki-laki, Islam telah memberikan kepadanya hak untuk mengambil keputusan dari dirinya sendiri, termasuk di dalamnya hak untuk menceraikan suami. Hak inilah yang dalam hukum Islam dikenal dengan istilah $k$ hulu', ${ }^{38}$ yang secara harfiyah berarti 'melepas'. Artinya, jika

\footnotetext{
38 Tentang tatacara khulu, dijelaskan dalam KHI sebagai berikut: (1) Seorang isteri yang mengajukan gugatan perceraian dengan jalan khuluk, menyanpaikan permohonannya kepada Pengadilan Agama yang mewilayahi tempat tinggalnya disertai alasan atau lasan-alasannya. (2) Pengadilan Agama selambat-lambatnya satu bulan memanggil isteri dan suaminya untuk didengar keterangannya masing-masing. (3) Dalam persidangan
} 
seorang isteri sudah tidak cocok lagi dengan suaminya, maka dia dapat meminta pengadilan untuk menceraikannya. Apabila terdapat alasan yang dapat dibenarkan secara hukum, maka pengadilan tidak berhak untuk menolaknya. Hal inilah yang dalam Peradilan Agama di Indonesia dekenal dengan Cerai gugat (gugatan perceraian). "Putusnya perkawinan yang disebabkan karena perceraian dapat terjadi karena talak atau berdasarkan gugatan perceraian". 39

Tentang masalah khulu' Asghar menambahkan keterangan, bahwa Islam barangkali merupakan agama pertama di dunia yang telah mengakui adanya hak semacam itu. Harus dicatat bahwa hak isteri untuk khulu' adalah mutlak dan tidak seorang pun dapat menghalanginya dalam mempergunakannya. ${ }^{40}$

Dengan demikian cukup jelas keterangan bahwa kesetaraan gender dalam talak adalah merupakan petunuk agama, jika terjadi perselisihan atau sesuatu sebab yang itu menjadi alasan kuat dalam memutuskan perkawinan, seorang suami dapat mentalaq isterinya, begitupun isteri dapat menggunakan hak khulu'-nya. Untuk lebih menjaga objektivitas sebuah persoalan yang menjadi titik pokok pengajuan cerai atau khulu', perlu adanya pihak ketiga yang berfungsi, di samping sebagai penengah yang mengupayakan penyatuan kembali (perdamaian) antara suami dan isteri, juga sebagai lembaga yang memutuskan sebuah perceraian atau putusnya perkawinan dengan khulu'. Dalam UU perkawinan 1974, dan diperkuat oleh KHI,

tersebut Pengadilan Agama memberikan penjelasan tentang akibat khulu', dan memberikan nasihat-nasihatnya. (4) Setelah kedua belah pihak sepakat tentang besarnya iwadh atau tebusan, maka Pengadilan Agama memberikan penetapan tentang izin bagi suami untuk mengikrarkan talaknya didepan sidang Pengadilan Agama. Terhadap penetapan itu tidak dapat dilakukan upaya banding dan kasasi. (Pasal 148, KHI)

${ }^{39}$ Lihat KHI, Pasal 114.

${ }^{40}$ Asghar kemudian memberi contoh dalam kasus Jamilah, istri Tsabit Ibn Qais. Jamilah sangat tidak puas dengan perkawinannya walaupun tidak ada perselisihan antara suami dan istri. Dengan pilu dia menyatakan kepada Nabi bahwa dia tidak menemukan kesalahan pada diri suaminya dalam hal moral dan agamanya; tetapi sama sekali dia tidak menyukainya. Nabi mengijinkannya bercerai asalkan dia mengembalikan kepada suaminya kebun buah-buahan yang telah diberikan kepadanya sebagai mas kawin. (Asghar Ali Engineer, op. cit., hlm. 195) 
misalnya, ditentukan bahwa perceraian hanya bisa dijatuhkan di depan pengadilan. ${ }^{41}[]$

\section{Daftar Pustaka}

Abdurrahman al-Jazairi, Al-Fiqh 'alâ Mazâhib al-Arba'ah, Istanbul: Dar ad-Da'wah, t.th.

Abu al-Fadl Syihab ad-Din as-Syayyid Mahmûd Afandi al-Alusi al-Bagdadi, Rûh al-Ma'âni fi Tafîir Al-Qur'ân al-'Azìm wa al-Sab'i al-Matsâni , t.t.p., Dar al-Fikr, t.th.

Abu Qasim Jarullah Mahmud Ibn Umar az-Zamakhsyari al-Khawarizmi, alKhasysyaf 'an Haqâiq at-Tanzil wa 'Uyun al-Aqâwi fi Wujûh at-Ta'wîl , Beirut, Dar al-Fikr, 1977.

Amina W. Muhsin, Wanita di dalam Al-Qur'an, Alih bahasa oleh Yaziar Radianti, Bandung: Pustaka, 1994.

A. Rahmat Rosyadi, Islam Problem Sex Kehamilan dan Melahirkan, Bandung: Angkasa, 1993.

Asghar Ali Engineer, Hak-hak Perempaun dalam Islam, terjemahan Farid Wajidi, Bandung, LSPPA, 1994.

Budhy Munawar-Rachman, "Islam dan Feminisme, dari Sentralisme kepada Kesetaraan", dalam Mansour Fakih et.al., Membincang Feminisme, Surabaya: Risalah Gusti, 1996.

Departemen Agama RI., Al-Qur'an dan Terjamahnya.

Ibnu Rusyd, Bidayatul Mujtahid, jilid II, terjemahan Imam Ghazali Said \& Ahmad Zaidun, Jakarta: Pustaka Amani, 2007.

Ibnu Taimiyah, Hukum-Hukum Perkawinan, Alih bahasa oleh Rusnan Yahya, Jakarta: Pustaka al-Kausar, 1997.

${ }^{41}$ Lihat Pasal 39, UU No. 1 tahun 1974: “Perceraian hanya dapat dilakukan di depan Sidang Pengadilan setelah Pengadilan yang bersangkutan berusaha dan tidak berhasil mendamaikan kedua belah pihak. Lihat juga Pasal 115, KHI: "Perceraian hanya dapat dilakukan di depan sidang Pengadilan Agama setelah Pengadilan gama tersebut berusaha dan tidak berhasil mendamaikan kedua belah pihak". 
Ibrahim Muhammad al-Jamal, Ibrahim Muhammad Al-Jamal, Fiqih Wanita, alih bahasa oleh Anshori Umar Sitanggal, Semarang: CV. Asy-Syifa', t.th.

Imam Hajar al-'Asqalani, Bulûg al-Marâm, Benaras, 1982.

Ken Suratiyah, "Pengorbanan Wanita Pekerja Industri", dalam Irwan Abdullah (Ed), Sangkan Paran Gender, Yogyakarta: Pusat Penelitian Kependudukan UGM, 1997

Kompilasi Hukum Islam (KHI).

Mahmûd Saltut, Al-Fatâwâ, Mesir: Dar al-Qalam, t.th.

Masdar F. Mas'udi, Islam dan Hak-Hak Reproduksi Perempuan: Dialog Fiqih Pemberdayaan, Bandung: Mizan, 1997.

Muhammad asy-Syarbini, Al-Iqna', Surabaya: Dar al-Ihya' al-Kutub al-Arâbiyyah, t.th.

Nasaruddin Umar, Argumen Kesetaraan Jender Perspektif al-Qur'an, Jakarta: Paramadina, 1999.

Sayyid Sabiq, Fiqhu al-Sunnah, Beirut: Dar Al-Fikr, t.th.

Siti Ruhaini Dzuhayatin, "Marital Rape, Bahasan Awal dari Perspektif Islam", dalam Eko Prasetyo \& Suparman Marzuki (Ed), Perempuan dalam Wacana Perkosaan, Yogyakarta: PKBI Yogyakarta, 1997.

Sri Suhandjati Sukri, (Ed.), Bias Jender dalam Pemahaman Islam, Yogyakarta: Gama Media, 2002.

Undang-Undang Perkawinan No. 1 Tahun 1974.

Wahbah al-Zuhaili, al-Figh al-Islâmy wa Adilatuhu, Damaskus: Dar al- Fikr. 
